\title{
Advanced microinjection protocol for gene manipulation using the model newt Pleurodeles walt
}

\author{
TOSHINORI HAYASHI*,1,2,3, MIE NAKAJIMA ${ }^{1}$, MITSUKI KYAKUNO ${ }^{1,2,3}$, KANAKO DOI $^{1}$, IKUMI MANABE1, \\ SHOUHEI AZUMA ${ }^{1}$ and TAKASHI TAKEUCHI ${ }^{1}$ \\ ${ }^{1}$ Department of Biomedical Sciences, School of Life Sciences, Faculty of Medicine, Tottori University, Yonago, Tottori, Japan, \\ ${ }^{2}$ Graduate school of Integrated Science for Life, Hiroshima University, Higashi-Hiroshima, Hiroshima, Japan and \\ ${ }^{3}$ Amphibian Research Center, Hiroshima University, Higashi-Hiroshima, Hiroshima, Japan.
}

\begin{abstract}
Urodele amphibian newts have an outstanding history as experimental animals in various research fields such as developmental biology and regeneration biology. We have reported a model experimental system using the Spanish newt, Pleurodeles waltl, and it enables reverse/ molecular genetics through gene manipulation. Microinjection is one of the core techniques in gene manipulation in newts. In the present study, we examined the conditions of the microinjection method, such as egg preparation, de-jelly solution, and formulation of injection medium. We have successfully optimized the injection protocol for $\boldsymbol{P}$ walt/ newts, and our improved protocol is more efficient and lower in cost than previous methods. This protocol can be used for the microinjection of plasmid DNA with I-Scel or mRNA, as well as genome editing using the CRISPR-Cas9 system. This protocol will facilitate research through gene manipulation in newts.
\end{abstract}

KEY WORDS: newt, microinjection, regeneration, transgenesis, genome editing

\section{Introduction}

Urodele amphibian newts have an outstanding history as an experimental animal in biology. Spemann first unveiled the function of an "organizer" in early embryogenesis using European newts (Spemann and Mangold, 1924). American newts were used for the study of neurobiology by Sperry (1943). Newts also have well known as a regenerative animal. In fact, they can regenerate various body parts, such as limbs, jaw, optical tissues, heart, and even the central nervous system (reviewed in Brockes and Kumar, 2002).

Newts have other unique biological properties such as large genome sizes (Elewa et al., 2017), tumor-resistance (Ingram, 1972; Okamoto, 1987), physiological polyspermy in their fertilization (Picheral, 1977; Charbonneau et al., 1983; Iwao, 2012), and sexual pheromones for mating-behavior (Nakada et al., 2017). Furthermore, Mouchet and other groups showed that newts are useful animals for toxicity testing of chemical compounds (Mouchet et al., 2007). Therefore, newts are valuable experimental animals for not only developmental biology and regeneration biology, but also various other research fields as well.

In order to investigate the mechanism of the unique biological properties of newts, Gallien and his colleagues found out outstanding properties of P. waltl as an experimental animal. After then, $P$. walt/ newts have a history of over 60 years of model newt and hundreds of researches have been published using this species (Gallien and Durocher, 1957; Shi and Boucaut, 1995). Recently, some groups had reported that the P. walt newts are available for reverse genetics and molecular genetics via gene manipulations because of its high fecundity and short generation time (Hayashi et al., 2013; Elewa et al., 2017).

Unlike conventional newts that have been commonly used thus far, such as the American common newt (Notophthalmus viridescens) or the Japanese common newt (Cynops pyrrhogaster), $P$. walt newts sexually mature within a year after fertilization and spawn a large number of eggs through all seasons in a laboratory (Hayashi et al., 2013). Genetic information such as drafting genome (Elewa et al., 2017) and gene model (Matsunami et al., in press) has been developed as a result of $P$. walt/ newts becoming a model animal. In addition, CRISPR/Cas9-mediated genome

Abbreviations used in this paper: HF, Holtfreter's solution.

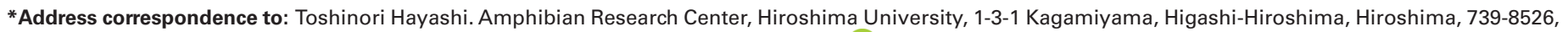
Japan. Tel: +81-82-424-7481. Fax: +81-82-424-0739. E-mail: toshih2@ hiroshima-u.ac.jp - (iD https://orcid.org/0000-0003-3676-5710
} 
editing methods have also been reported CRISPR/Cas9 (Elewa et al., 2017; Suzuki et al., 2018). These facts make it easy to perform gene manipulation using newts.

Microinjection into fertilized eggs is one of the most important techniques for gene manipulation in newts. Microinjection technique for the $P$. walt/ newts originally was developed by Moreau et al., (1980) for protein injection into the oocytes. And then, microinjection had been applied for gene manipulation for Japanese common newts and $P$. walt/ newts (Makita et al., 1995; Casco-Robles et al., 2011; Hayashi et al., 2013; Hayashi and Takeuchi, 2015; Hayashi and Takeuchi, 2016). However, in the previous protocols, the yield of embryos after injection was not high enough, because egg preparation was hampered. Furthermore, the injection medium was insufficient to support the newt eggs because of its low-viscosity. In addition, the cost of the injection medium was expensive because a Ficoll-base formulation method was used.

In the present study, we have optimized the conditions for egg preparation. We used methylcellulose for the injection medium instead of Ficoll in order to generate sufficient viscosity. Our methylcellulose-based injection medium made it easier to perform the microinjection procedure. At the same time, the methylcellulose reduced the cost of the injection medium. As a result, we have established an improved microinjection protocol for a new experimental model animal, $P$. waltl.

\section{Experimental Protocols}

\section{Animal care}

Iberian ribbed newts (Pleurodeles walt) used in this study were raised from a closed colony at Tottori University. The newts were reared at $24-26^{\circ} \mathrm{C}$ in tap water. Animals were fed with hatched blain shrimp for larvae or compound feeds (Kyorin, Hyogo, Japan) for juvenile/adult newts. All procedures were carried out in accordance with the guidelines of the Institutional Animal Care and Use Committee of Tottori University (Tottori, Japan) and national guidelines of the Ministry of Education, Culture, Sports, Science \& Technology in Japan.

\section{Reagents}

10x Holtfreter's solution (10x HF)

Dissolve $35 \mathrm{~g} \mathrm{NaCl}(600 \mathrm{mM}), 0.5 \mathrm{~g} \mathrm{KCl}(7 \mathrm{mM})$ and $2 \mathrm{~g} \mathrm{NaHCO}_{3}$ $(24 \mathrm{mM})$ in $1 \mathrm{~L}$ of distilled water. Sterilize by autoclaving.

\section{$100 \%$ HF solution}

Add $100 \mathrm{~mL} 10 \times \mathrm{HF}$ solution to $900 \mathrm{~mL}$ distilled water. Sterilize by autoclaving and allow it to cool at room temperature. Add $5 \mathrm{~mL}$ of $1 \mathrm{M} \mathrm{HEPES}$ (final $5 \mathrm{mM}$ ), $1 \mathrm{~mL}$ of $1 \mathrm{M} \mathrm{CaCl}_{2}$ (final $1 \mathrm{mM}$ ) and 1 $\mathrm{mL}$ of $1 \mathrm{M} \mathrm{MgSO}_{4}$ (final $1 \mathrm{mM}$ ) to this solution.

\section{5\% HF solution}

Add $25 \mathrm{~mL} 10 \times \mathrm{HF}$ solution to $975 \mathrm{~mL}$ distilled water and sterilize by autoclaving. Allow the solution to cool at room temperature and add $5 \mathrm{~mL}$ of $1 \mathrm{M} \mathrm{HEPES,} 1 \mathrm{~mL}$ of $1 \mathrm{M} \mathrm{CaCl}_{2}, 1 \mathrm{~mL}$ of $1 \mathrm{M} \mathrm{MgSO}_{4}$ and $1 \mathrm{~mL}$ of $10 \mathrm{mg} / \mathrm{mL}$ gentamicin sulfate solution (final $10 \mu \mathrm{g} /$ $\mathrm{mL})$. Store at $4^{\circ} \mathrm{C}$.

\section{De-jellying solution}

Dissolve $0.5 \mathrm{~g}$ of cysteine in $100 \mathrm{~mL} 25 \% \mathrm{HF}$ solution (final
0.5\% cysteine). Use cell culture grade product (Sigma C7352). Prepare just before use. (Sodium Thioglycolate is also available. See Supp. Fig. 1).

\section{Injection medium}

Add $12.5 \mathrm{~mL} 10 \times \mathrm{HF}$ solution to $487 \mathrm{~mL}$ distilled water and heat to $60-80^{\circ} \mathrm{C}$. Next, add $3.75 \mathrm{~g}(0.75 \%)$ of methylcellulose (Sigma M0262, $400 \mathrm{cP})$. Put a magnetic stirrer bar into the bottle and mix. Sterilize by autoclaving, and then mix again with a magnetic stirrer with cooling to dissolve methylcellulose. Add $2.5 \mathrm{~mL}$ of $1 \mathrm{M}$ HEPES, $0.5 \mathrm{~mL}$ of $1 \mathrm{M} \mathrm{CaCl}_{2}, 0.5 \mathrm{~mL}$ of $1 \mathrm{M} \mathrm{MgSO}_{4}, 4.5 \mathrm{~mL}$ of $1 \mathrm{M}$ $\mathrm{MgCl}_{2}$, and $0.5 \mathrm{~mL}$ of $10 \mathrm{mg} / \mathrm{mL}$ gentamicin sulfate. Store at $4{ }^{\circ} \mathrm{C}$. (6\% Ficoll solution is also available instead of methylcellulose, see Supp. Fig. 2).

\section{Anesthetic solution}

Dissolve $0.2-0.4 \mathrm{~g}$ of ethyl 3-aminobenzoate methanesulfonate in $400 \mathrm{~mL}$ 25\% HF solution. Prepare just before use.

\section{Gonadotropin solution ( $h C G$ )}

Dissolve 1000 units of human chorionic gonadotropin into 1 $\mathrm{mL}$ of $100 \% \mathrm{HF}$ solution. Store at $-20^{\circ} \mathrm{C}$. It should be stable after several freeze-thawing cycles.

\section{Transgenes (injection-solutions)}

\section{Plasmid vectors}

Use I-Scel site containing vectors with I-Scel enzyme (NEB) in order to achieve efficient integration into the genome (Ogino et al., 2006).

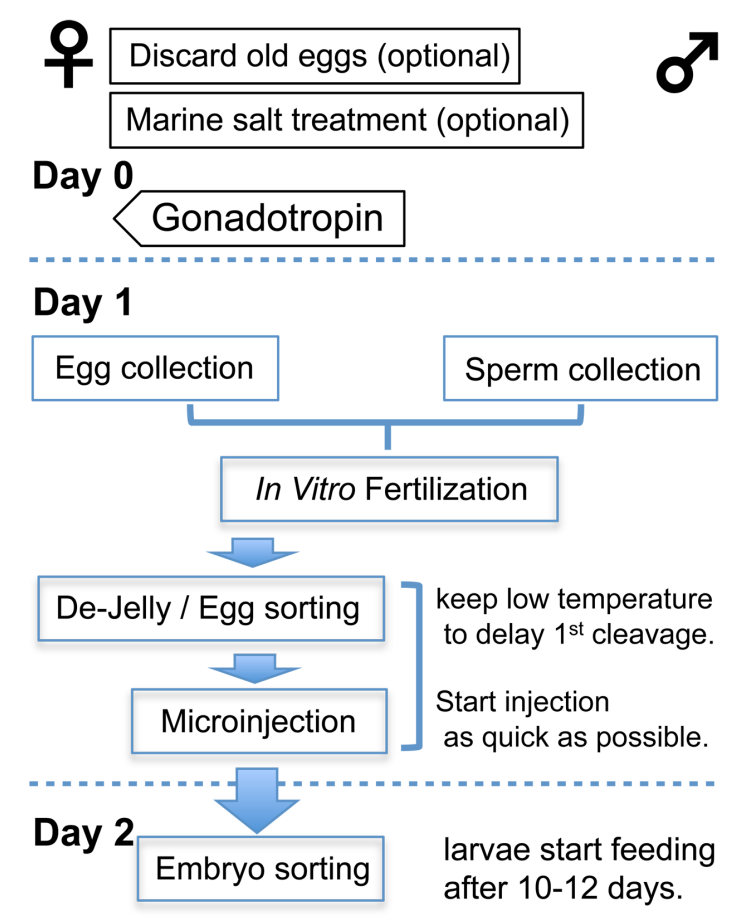

Fig. 1. Flow chart of the microinjection procedure. In order to obtain high quality eggs, start optional steps (pre-treatment) more than 2 weeks before Day 0. 
Fig 2. Sperm, egg collection and in vitro insemination. (A) Sperm collection from anesthetized male newts under a stereomicroscope. (B) Higher magnification of the cloaca and sperm sucked up with the micropipette (also see video "Sperm collection"). (C) Egg collection from anesthetized female animal. Collect eggs in a dry plastic dish while pushing the abdomen (also see movie "Egg collection"). (D) The sperm suspension was mixed with the eggs for insemination.
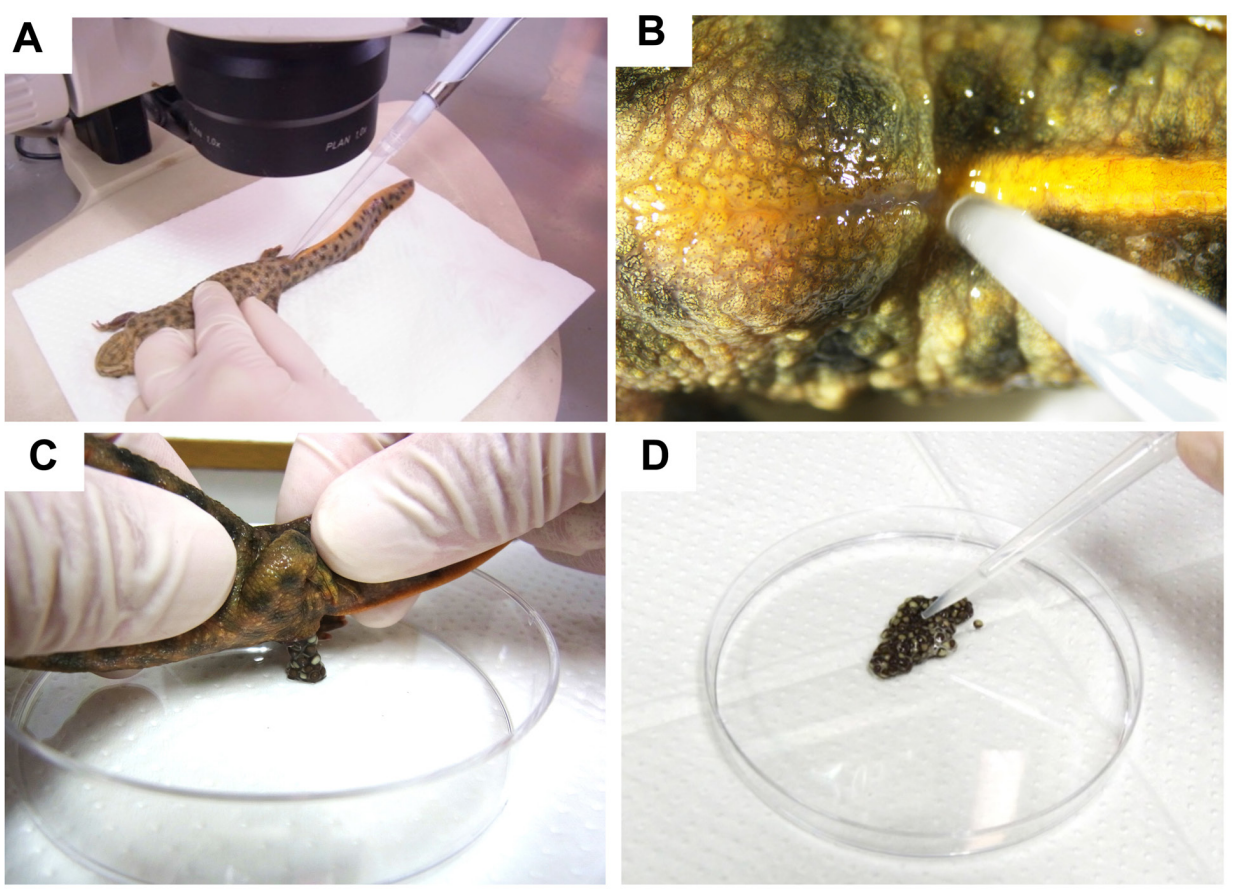

Prepare the plasmid vectors using ion exchange columns (e.g. NucleoBond, TAKARA Bio or Plasmid Midi kit, QIAGEN). Silica membrane columns are not recommended even with the endotoxin-free protocol.

Digest $100-400 \mathrm{ng}$ of the plasmids in $20 \mu \mathrm{L}$ of I-Scel solution (1 X I-Scel buffer, 23-46 units of I-Scel, BSA is not necessary) at $37^{\circ} \mathrm{C}$ for $40 \mathrm{~min}$.

Optimize the amount of the DNA between 50 - $400 \mathrm{pg} / \mathrm{egg}$.

\section{2. $m R N A$}

To synthesize the mRNAs by in vitro transcription, the template DNA must contain T7, T3, or SP6 promoter. The 5-prime ends of the RNAs must be capped. It is easy to use a kit for capped-mRNA synthesis (e.g. mMESSAGE mMACHINE Kit, Life Technologies).

2.1 Linearize 2-10 $\mu \mathrm{g}$ of plasmid vectors with appropriate restriction enzymes.

2.2 Synthesize the mRNAs by in vitro transcription using the appropriate RNA polymerase.

2.3 Purify the mRNAs by ethanol precipitation or column purification (MEGAclear, Life Technologies), and dissolved in nuclease-free water $(100-500 \mathrm{ng} / \mu \mathrm{L})$. Store at $-80^{\circ} \mathrm{C}$.

2.4 Just before use, dilute RNAs with RNAse-free water to $100-500 \mathrm{ng} / \mu \mathrm{L}$. Optimize the amount of mRNA between $100 \mathrm{pg}$ -2 ng/egg.

\section{Equipment}

1. Stereo-microdissection scopes with fiber lighting

2. Microinjector and micromanipulator: The authors used a NANOJECT II microinjector (Drummond). However, other types of microinjector such as FemtoJet (Eppendorf) should also be fine.

3. Injection-dish (Nunc mini tray, 60 wells)

4. Low-temperature incubator (temperature range $; 6^{\circ} \mathrm{C}$ to $25^{\circ} \mathrm{C}$ )

5. Puller and glass capillaries for making the glass needles: Use glass capillaries adapted for the microinjector.
6. Transfer pipets: Cut a tip of the plastic pipet $(3-5 \mathrm{~mL})$ to adjust its opening for the eggs or embryos.

\section{Procedure (diagramed in Fig. 1)}

\section{Sperm collection(Figure 2 and video "Sperm collection")}

1.1 Transfer some sexually matured male newts (older than 6 months post fertilization) into the anesthetic solution. When the newts are anesthetized, wipe the animals lightly to remove water drops.

1.2 Press lightly on the abdomen of the newts to excrete the urine. When squeezing the sperm strongly with urine in the bladder, the bladder will break and the newt will die.

1.3 Squeeze the sperm by pressing the abdomen until the sperm seep out of the cloaca. Collect with a pipette and transfer to a microtube containing $300-500 \mu \mathrm{L}$ of $100 \% \mathrm{HF}$. Sperm can be collected from the same animals every $2-4$ weeks.

1.4 Leave the microtube at room temperature for 20-30 min. Then, gently tap the microtube to suspend the sperm. The sperm suspension is slightly cloudy. The sperm will die if mixed vigorously.

1.5 The sperm suspension can be stored for up to 4 hours at room temperature.

Sperm concentration of $2000 \mathrm{sperm} / \mu \mathrm{L}$ is sufficient (Supp. Fig. 3). If the fertilization rate is low, confirm the sperm concentration.

\section{Egg collection (Figure 2 and video "Egg collection")}

2.1 (Optional) In order to obtain high quality eggs, keep the female newts (older than 9 months) in an aquarium supplied with $6 \mathrm{~g} / \mathrm{L}$ of Tetra Marine salt (artificial seawater, provided by Spectrum Brands Ltd., Atlanta, GA) for more than 2 weeks (Supp. Fig. 4). It may be unnecessary depending on the water quality of the breeding facility.

2.2 (Optional) when the spawning interval is longer than 8 weeks, the female will lay over-maturated eggs. In such a case, discard old 
A Good-quality eggs

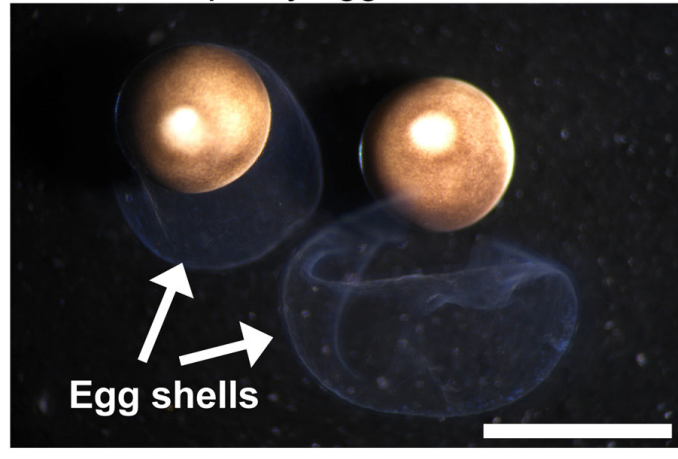

B Low-quality (collapsed or leaking)

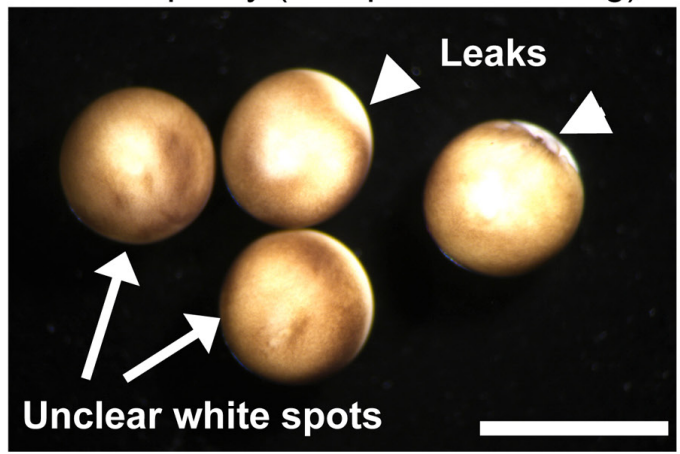

C Eggs in the microinjection dish

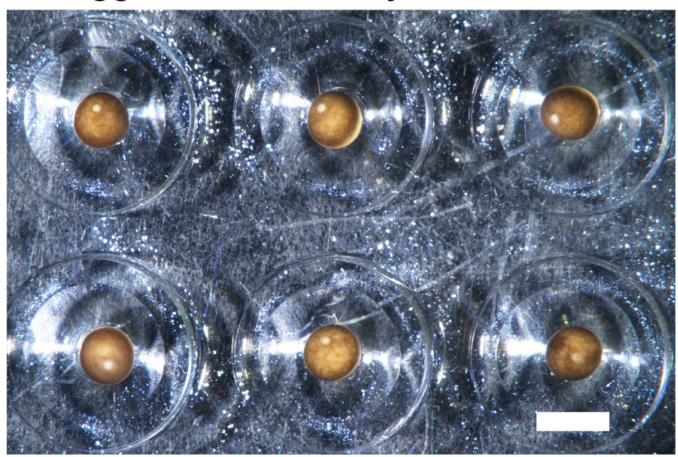

Fig 3. Egg sorting and microinjection. (A) Good quality eggs. The animal pole sides are clearly pigmented, and a white spot on the animal pole was a sign of good-quality eggs. There was no leak of cytoplasm. (B) On the other hand, a white spot was blurred or difficult to see on low quality eggs (arrows). These eggs also showed leak of cytoplasm (arrowheads in B). (C) After eggshell removal, they settled in the well at the bottom of the injection dish. Scale bars $2 \mathrm{~mm}$.

eggs by administration of 100-200 units of hCG 2 weeks before the injection (Supp. Fig. 4).

2.3 To stimulate ovulation, inject 100-200 units hCG subcutaneously into the lower jaw of mature females, 14 to 18 hours prior to egg collection. The egg collection should be finished before 24 hours after hCG injection otherwise the quality of the eggs will decline after that period.

2.4 The next day, when the female newts start spawning, anesthetize the newts in the anesthetic solution. Wipe the newts lightly to remove water drops and then push the abdomens gently and collect the eggs in a dry plastic dish $(\phi 100 \mathrm{~mm})$. After egg collec- tion, quickly move to insemination.

\section{Artificial insemination and fertilized egg (single-stage embryo) preparation}

3.1 Add sperm suspension to the eggs (approximately 10-20 $\mu \mathrm{L}$ per 20 eggs) by pipet, and then mix gently using pipette tips.

3.2 Incubate inseminated eggs at room temperature for $5 \mathrm{~min}$. Cover the plastic dish with the lid to prevent the eggs from drying out.

3.3 Pour 25\% HF into the dish, and incubate eggs for a further 10-15 min to allow water absorption by the jelly.

3.4 Remove the fertilized eggs from the bottom of the plastic dish and then transfer the eggs into the de-jelly solution using the transfer pipet.

3.5 Soak the fertilized eggs in de-jelly solution for $30-60 \mathrm{sec}$ with gentle shaking and then rinse the eggs 5 times in $25 \% \mathrm{HF}$ solution.

3.6 Incubate the eggs at $8^{\circ} \mathrm{C}$ for $20-30 \mathrm{~min}$ in $25 \% \mathrm{HF}$ solution. During this period, any remaining jelly melts away.

3.7 Sort good quality eggs (Fig. 3 A,B) under a stereomicroscope and transfer them into an injection-dish filled with injection medium.

3.8 Remove the eggshells using fine forceps. The eggs without a shell settle in the well at the bottom (Fig. 3C, video "Eggshell removal"); it helps to hold the eggs during microinjection.

3.9 Store the eggs at $6-8^{\circ} \mathrm{C}$ until microinjection.

\section{Microinjection}

4.1 Set up the microinjector and the glass needle filled with injection-solution (DNA, RNA, or proteins) according to the manufacturer's protocol. The opening of the glass needle should be 10-30 $\mu \mathrm{m}$. Adjust the injection volume to between 9-30 nL.

4.2 Take out the injection tray from the incubator and put it under the injector.

4.3 Support gently the egg with the forceps, and prick the animal pole side with the glass needle.

4.4 Inject the injection-solution, and then pull out the needle.

4.5 Leave the injected eggs, and move to the next one. Repeat steps 3-5 until all eggs have been injected. To obtain fully transgenic or full knockout animals, it is important to inject at the single-cell embryo stage. Therefore, the injection is performed as quickly as possible after fertilization.

4.6 Incubate the injected eggs at room temperature overnight.

4.7 (Optional) After injection of DNA, incubate the eggs (embryos) at $10-12^{\circ} \mathrm{C}$ for $4-8$ hours to delay the first cleavage, and then keep at $16^{\circ} \mathrm{C}$ overnight. This step might facilitate integration of the injected DNA into the newt genome.

\section{Embryo sorting}

5.1 Transfer normally developing embryos into petri dishes or plastic cups filled with $25 \%$ HF solution using a transfer pipet (Fig. $4 \mathrm{~A}, \mathrm{~B})$. The criteria for the developing stages were defined by Shi and Boucaut (1996).

5.2 Rinse the embryos $2-3$ times in $25 \%$ HF solution.

5.3 Incubate the embryos in $25 \%$ HF solution for $6-8$ days (hatching-stage) and then transfer them into tap water. Start feeding with blain shrimp after 10-12 days post fertilization.

5.4 (Optional) Examination of the expression of the transgene. Expression of a reporter protein such as a fluorescent protein can be confirmed under a fluorescent stereomicroscope.

5.5 Sort intended transgenic or knockout animals by expression of the reporter gene or genotyping. 
A Normal embryo

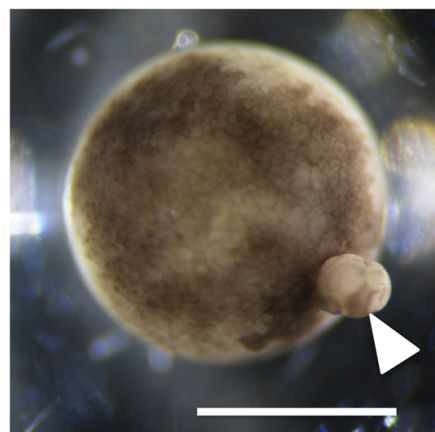

\section{B Developing defect}

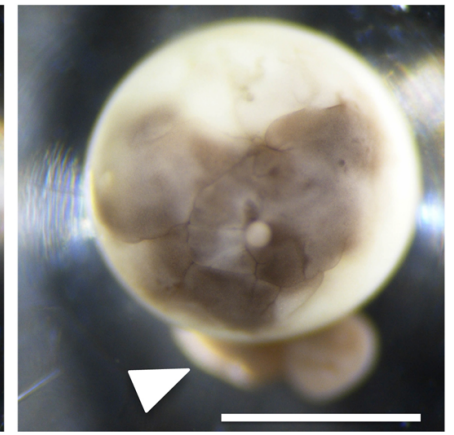

C No-injection, 6 hours
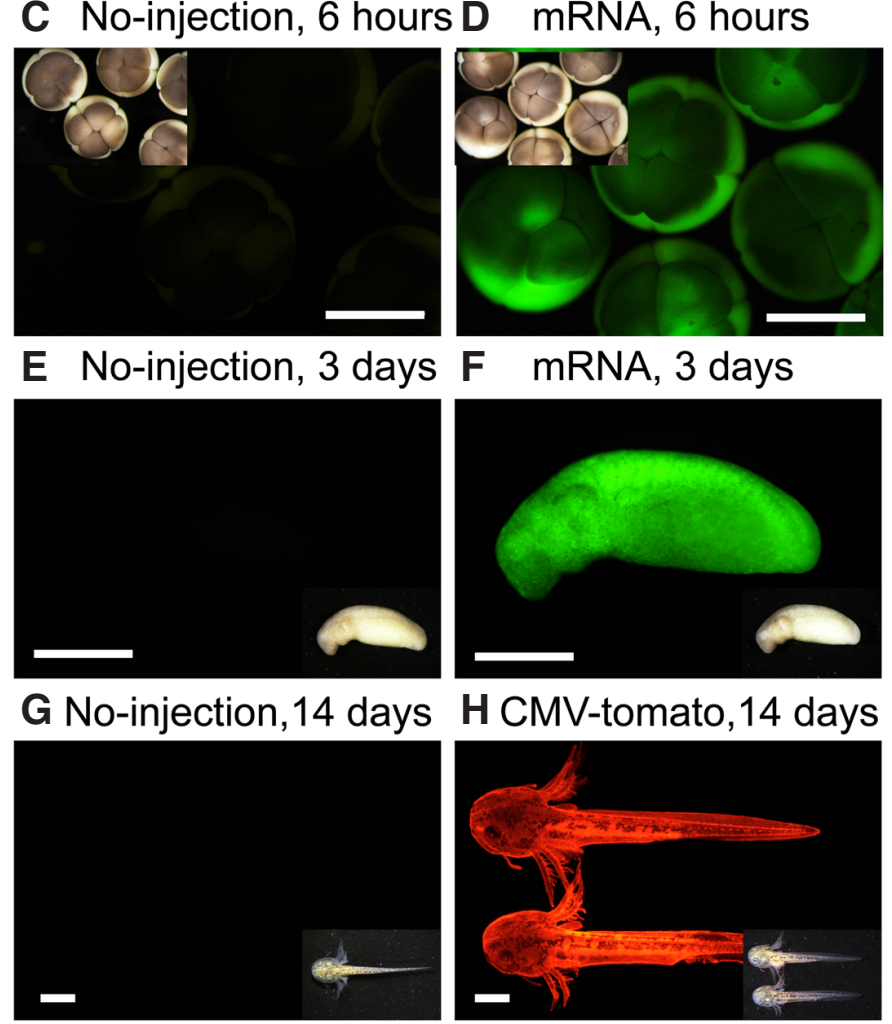

Fig 4. Embryo sorting and anticipated results. Typical examples of normally developing embryo, blastula stage (A) and developing defect (B). The embryo in (B) showed abnormal cleavage. Arrows indicate leaked cytoplasm. Bars: $1 \mathrm{~mm}$. (C-F) GFP expression in GFP-mRNA (1 ng/egg) injected embryos (D,F) and un-injected controls (C,E). All embryos were incubated at $25^{\circ} \mathrm{C}$. (C,D) Exposure for 3 seconds, whereas $(E, F)$ were exposed for $300 \mathrm{~ms}$ under a green filter. Insets show the bright fields views. Bars: $1 \mathrm{~mm}$. $(\mathrm{G}, \mathrm{H})$ RFP expression in CMV driven tdTomato plasmid vector (110 pg/egg) injected embryos (G) and un-injected controls (H). Photos were exposed for 300 ms under a red filter. Insets show the bright field views. Bars: $1 \mathrm{~mm}$.

5.6 (Optional) For genotyping, collect the tail tips or limb tips under anesthesia $(0.01 \%$ ethyl 3 -aminobenzoate methanesulfonate is suitable for the larvae).

5.7 Raise these animals to the desired stages. To increase the growth rate of the animals, the optimal temperature range is $24-26^{\circ} \mathrm{C}$. However, they can be maintained in a healthy state at $16-23^{\circ} \mathrm{C}$.

\section{Results and Discussion}

Anticipated results obtained from our injection protocol are shown in Fig. 4. When mRNA is injected, fluorescence can be confirmed after about 6 hours (Fig. 4 C-F). In the case of plasmid DNA, it depends on the enhancer/promoter activity (Fig. 4G and $\mathrm{H})$, but fluorescence can be confirmed at least after 24-36 hours (depend on temperature). Therefore, expression of the transgene was thought to begin after mid-blastula transition.

We examined the conditions of the microinjection method, such as egg preparation (Supp. Fig. 4), de-jelly solution (Supp. Fig. 1), and formulation of injection medium (Supp. Fig. 2). Finally, we have improved the microinjection protocol for a new model animal, $P$. walt/ newts.

In the new protocol, the survival rate was increased by changing the conditions for the de-jelly treatment (Supp. Fig. 1). Sodium thioglycolate ( $2 \%$ dissolved in $25 \%$ HF, 5 min) can be used instead of cysteine solution. After Sodium thioglycolate treatment, the eggshell becomes soft and easier to remove than with cysteine treatment. However, the ratio of normal embryos would decline slightly compared to cysteine solution $(0.5 \%$ dissolved in $25 \% \mathrm{HF}$, $30 \mathrm{sec}$, see Supp. Fig. 1).

We also applied and optimized the methylcellulose-based injection medium for the $P$. walt/ originally developed for Xenopus (Tanigawa etal., 2009). Since the methylcellulose-injection medium has a low specific gravity and high viscosity, it is easy to perform the injection operation compared to the Ficoll-based injection medium. The survival rate in methylcellulose-injection medium was not different from the survival rate in Ficoll-injection medium used in previous protocols (Supp. Fig. 2). In addition, the cost of the methylcellulose-injection medium was $1 / 10$ that of a Ficoll-based medium. Finally, the salt for artificial seawater was a useful option for obtaining high quality eggs (Supp. Fig. 4).

In the present study, we showed the typical results obtained by injection of DNA vectors and mRNA. However, our microinjection protocol can be used for Genome Editing using the CRISPR/Cas9 system (Suzuki et al., 2018).

The $P$. walt/ newt is a very useful laboratory animal for various research fields, such as developmental biology, neurobiology, cancer research, evolution, ethology, toxico-genomics, and regeneration biology. This microinjection protocol will increase the value of the newts as an experimental model. Furthermore, there is a possibility that this protocol can also be applied to other newts or Urodele amphibians such as axolotls, and Frogs (eg. Xenopus). This protocol will facilitate research through gene manipulation not only in newts but amphibians.

\section{Acknowledgments}

We would like to thank Kyorin Corporation (Hyogo, Japan) for kindly providing feed for the newts. This research was supported by MEXT/JSPS KAKENHI (grant numbers, JP16H01254, JP16K08467, and 16H04794).

\section{References}

BEETSCHEN J C (1995) The embryonic development of Pleurodeles waltl (Michah). Reappraisal of the Gallien-Durocher stage series. Int J Dev Biol 39: 425-426.

BROCKES J P, Kumar A (2002) Plasticity and reprogramming of differentiated cells in amphibian regeneration. Nat Rev Mol Cell Biol 3: 566-574.

CASCO-ROBLES M, Yamada S, Miura T, Nakamura K, Haynes T, Maki N, DEL RIO- 
TSONIS K, TSONIS PA, CHIBA C (2011) Expressing exogenous genes in newts by transgenesis. Nat Protoc 6: 600-608.

CHARBONNEAU M, MOREAU M, PICHERAL B, VILAIN J P, GUERRIER P (1983) Fertilization of amphibian eggs: A comparison of electrical responses between anurans and urodeles. Dev Biol 98: 304-318.

ELEWA A, WANG H, TALAVERA-LÓPEZ C, JOVEN A, BRITO G, KUMAR A, HAMEED LS, PENRAD-MOBAYED M, YAOZ, ZAMANI N, ABBAS Y, ABDULLAYEV I, SANDBERG R, GRABHERR M, ANDERSSON B, SIMON A (2017) Reading and editing the Pleurodeles walt genome reveals novel features of tetrapod regeneration. Nat Commun 8: 2286.

HAYASHI T, TAKEUCHI T (2015) Gene manipulation for regenerative studies using the Iberian ribbed newt, Pleurodeles waltl. Methods Mol Biol 1290: 297-305.

HAYASHI T, TAKEUCHI T (2016) Mutagenesis in Newts: Protocol for lberian Ribbed Newts. Methods Mol Biol 1338: 119-126.

HAYASHI T, YOKOTANI N, TANE S, MATSUMOTO A, MYOUGA A, OKAMOTO M, TAKEUCHI T (2013) Molecular genetic system for regenerative studies using newts. Dev Growth Differ 55: 229-236.

GALLIEN L, DUROCHER M (1957) Table chronologique du developpement chez Pleurodeles waltlii (Michah). Bull Biol Fr Belg 91: 97-114.

INGRAM AJ (1972) The lethal and hepatocarcinogenic effects of dimethylnitrosamine injection in the newt Triturus helveticus. Br J Cancer 26: 206-215.

IWAO Y (2012) Egg activation in physiological polyspermy. Reproduction 144: 11-22.

MAKITA R, KONDOH H, OKAMOTO M (1995) Transgenesis of newt with exogenous gene expression facilitated by satellite 2 repeats. Dev Growth and Differ37:605-616.

SPEMANN H, MANGOLD O (1924) Über Induktion von Embryonalanlagen durch Implantation artfremder Organisatoren. Arch Mikrosk Anat En 100: 599-638

MATSUNAMI M, SUZUKI M, HARAMOTO Y, FUKUI A, INOUE T, YAMAGUCHI K, UCHIYAMA I, MORI K, TASHIRO K, ITO Y, TAKEUCHI T, SUZUKI K T, AGATA Kiyokazu A, SHIGENOBU S, HAYASHI (2019) A comprehensive reference transcriptome resource for the Iberian ribbed newt Pleurodeles waltl, an emerging model for developmental and regeneration biology. DNA Research, in press. (doi: 10.1093/dnares/dsz003)
MOREAUM, LECLERC C, GUALANDRIS-PARISOT L, DUPRATAM (1980) Increased internal $\mathrm{Ca} 2+$ mediates neural induction in the amphibian embryo. Proc Natl Acad Sci USA. 91: 12639-12643.

MOUCHETF, GAUTHIER L, BAUDRIMONTM, GONZALEZP, MAILHESC, FERRIER V, DEVAUX A (2007) Comparative evaluation of the toxicity and genotoxicity of cadmium in amphibian larvae (Xenopus laevis and Pleurodele walt) using the comet assay and the micronucleus test. Environ Toxicol 22: 422-435.

NAKADAT, TOYODAF, MATSUDAK, NAKAKURAT, HASUNUMAI, YAMAMOTOK, ONOUE S, YOKOSUKA M, KIKUYAMA S (2017) Imorin: a sexual attractiveness pheromone in female red-bellied newts (Cynops pyrrhogaster). Sci Rep 7: 41334

NOWOSHILOW S, SCHLOISSNIG S, FEI J F, DAHL A, PANG A W C, PIPPEL M, WINKLER S, HASTIE A R, YOUNG G, ROSCITO J G, FALCON F, KNAPP D, POWELL S, CRUZ A, CAO H, HABERMANN B, HILLER M, TANAKA E M, MYERS E W (2018) The axolotl genome and the evolution of key tissue formation regulators. Nature 554: 50-55.

OGINO H, MCCONNELL WB, GRAINGER RM (2006) High-throughput transgenesis in Xenopus using I-Scel meganuclease. Nat Protoc 1: 1703-1710.

OKАMOTO M (1987) Induction of ocular tumor by nickel subsulfide in the Japanese common newt, Cynops pyrrhogaster. Cancer Res 47: 5213-5217.

PICHERAL B (1977) Fertilization in triturus Pleurodeles. Passage through the ovum envelope by spermatozoa. J Ultrastruct Res 60: 106-120.

SHI D L, BOUCAUT J C (1995) The chronological development of the urodele amphibian Pleurodeles waltt (Michah). Int J Dev Biol 39: 427-441.

SPERRY R W (1943) Effect of 180 degree rotation of the retinal field on visuomotor coordination. J Exp Zool 92: 263-279.

SUZUKIM, HAYASHIT, INOUET, AGATAK, HIRAYAMAM, SUZUKI M, SHIGENOBU S, TAKEUCHI T, YAMAMOTO T, and SUZUKIK T (2018) Cas9 ribonucleoprotein complex allows direct and rapid analysis of coding and noncoding regions of target genes in Pleurodeles walt/development and regeneration. Dev Biol 443: 127-136.

TANIGAWA Y, IKENISHI K, and KOMIYA T (2009) A novel method for microinjection into Xenopus eggs and embryos supported in methylcellulose solution. Int J Dev Biol 53: 1053-1056. 


\section{Further Related Reading, published previously in the Int. J. Dev. Biol.}

What mechanisms drive cell migration and cell interactions in Pleurodeles?

J C Boucaut, L Clavilier, T Darribère, M Delarue, J F Riou and D L Shi

Int. J. Dev. Biol. (1996) 40: 675-683

http://www.intjdevbiol.com/web/paper/8877440

Primordial germ cell development: is the urodele pattern closer to mammals than to anurans?

M Wakahara

Int. J. Dev. Biol. (1996) 40: 653-659

http://www.intjdevbiol.com/web/paper/8877437

How did urodele embryos come into prominence as a model system?

J C Beetschen

Int. J. Dev. Biol. (1996) 40: 629-636

http://www.intjdevbiol.com/web/paper/8877434

What are the key advantages and disadvantages of urodele species compared to anurans as a model system for experimental analysis of early development?

P D Nieuwkoop

Int. J. Dev. Biol. (1996) 40: 617-619

http://www.intjdevbiol.com/web/paper/8877432

The chronological development of the urodele amphibian Pleurodeles waltl (Michah) D L Shi and J C Boucaut

Int. J. Dev. Biol. (1995) 39: 427-441

http://www.intjdevbiol.com/web/paper/7577434

The embryonic development of Pleurodeles waltl (Michah). Reappraisal of the GallienDurocher stage series

J C Beetschen

Int. J. Dev. Biol. (1995) 39: 425-426

http://www.intjdevbiol.com/web/paper/7577433

Primordial germ cell proliferation in the salamander Pleurodeles waltl: genetic control before gonadal differentiation

C Dournon, C Demassieux, D Durand and M Lesimple

Int. J. Dev. Biol. (1989) 33: 477-485

http://www.intjdevbiol.com/web/paper/2641353
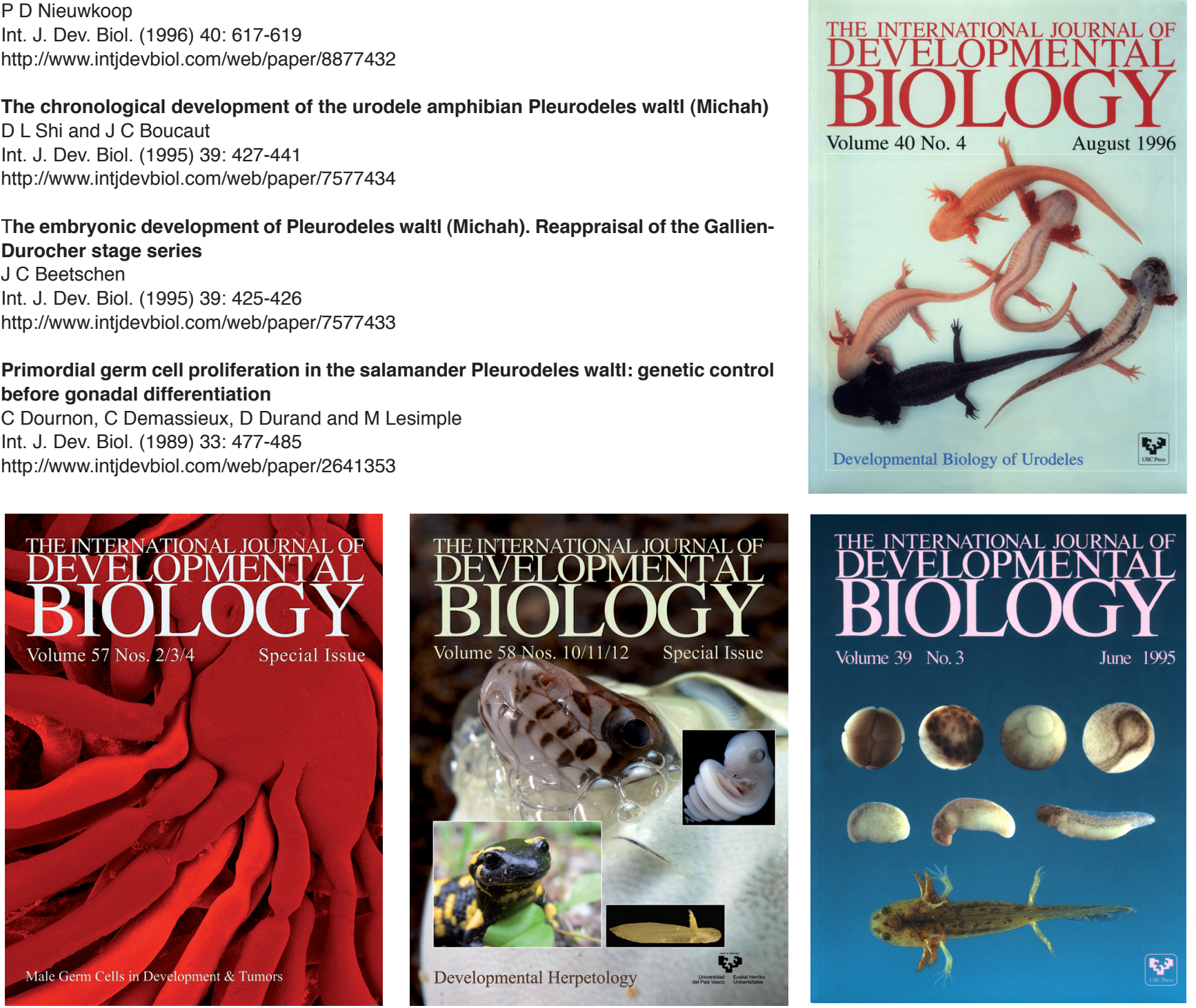